\title{
EKSPLORASI VISUAL GANG KELINCI PASAR BARU JAKARTA SEBAGAI DASAR PERANCANGAN SET FILM ANIMASI PENDEK
}

\author{
Rizky Ramadhan'), Arik Kurnianto ${ }^{2)}$ \\ School of Design-Animation, Binus University \\ rizram96@binus.ac.id ${ }^{I)}$ arikkurnia@binus.ac.id ${ }^{2}$
}

\begin{abstract}
Abstrak
Penelitian ini bertujuan untuk mengetahui tentang lingkungan di sekitar Gang Kelinci, termasuk juga visualisasi rumah dan aktivitas kegiatan keseharian masyarakat yang hidup di lingkungan tersebut. Penelitian ini menggunakan metode kualitatif yaitu melakukan observasi terhadap Gang Kelinci dan melakukan studi literatur terkait tentang Gang Kelinci. Penelitian ini memberikan informasi yang akan digunakan dalam merancang konsep set film animasi pendek. Perancangan ini akan diolah berdasarkan teori Mise-en-Scene dan didasari atas referensi lainnya sebagai suatu konsep desain animasi pendek.
\end{abstract}

Keywords: Visualisasi, Set, Gang Kelinci, Mise-en-scène, Animasi pendek

\begin{abstract}
The goal of research was to know environment of Gang Kelinci that include visual form of house and life style of people that lives there. This research uses qualitative methods which is observation into Gang Kelinci and also looking for some article that related about Gang Kelinci. Which would be gained an information that would be used to make a concept environment of short animation. Which would be further developed base on Theory of Mise-en-scène' and any others reference as a concept design of Short Animation.
\end{abstract}

Keywords: Visualitation, Set, Gang Kelinci, Mise-en-scène', Short Animation 


\section{PENDAHULUAN}

Jakarta merupakan salah satu kota besar di Indonesia yang menjadi sebuah salah satu destinasi wisata masyarakat Indonesia. Banyak beberapa tempat destinasi wisata di Jakarta yang unik dan banyak mengandung nilai sejarah dan keindahan yang jarang kita tau didalamnya. Setiap daerah tersebut memiliki ciri yang berbeda, sehingga menghasilkan suasana yang berbeda dari tiap tiap tempatnya. Yang membedakan dari setiap daerah wisata di Jakarta adalah struktur bangunan dan tata kota dari setiap daerahnya, mulai dari gaya arsitektur, hiasan hiasan hingga kehidupan masyarakat setempat lah yang membangun suasana daerah tersebut hingga berbeda dan bercirikhas dari setiap tempatnya.

Salah satunya adalah Gang Kelinci, yang merupakan daerah yang jarang diketahui banyak masyarakat diluar kota Jakarta, namun sangat dikenal banyak masyarakat local kota Jakarta itu sendiri.Gang Kelinci merupakan salah satu daerah pemukiman yang unik yang dimana banyak memiliki sejarah dari nama tempat itu sendiri, sehingga akan sangat menarik untuk mengetahui lebih jauh dan lebih dalam arti dari daerah tersebut. Stuktur bangunan yang sederhana pada daerah tersebut juga memiliki keunikan tersendiri dari yang membuat daerah tersebut sangat menonjol dan berbeda dari daerah sekitarnya yang cenderung sudah sangat cenderung lebih maju dan tertata rapih di setiap penempatannya. Salah satunya ialah posisi lokasi Gang Kelinci itu sendiri merupakan pemukiman warga yang cenderung memiliki bentuk bangunan sederhana, yang dikelilingi oleh gedung gedung di Jakarta. Karena kesederhanaanya, daerah tersebut memiliki nilai konten lokal yang tinggi sehingga akan sangat unik untuk diteliti lebih dalam.

Pada umumnya set pada sebuah film animasi memiliki dasar ide atau pemikiran pemikiran yang ingin diangkat untuk membentuk sebuah konsep dalam membangun suasana, latar belakang cerita, hingga latar waktu dalam film animasi. Sehingga dengan dasar itulah akan sangat unik untuk menjadi dasar dalam membuat suatu suasana dalam sebuah film animasi yang cenderung masih sedikit film animasi di Indonesia yang menonjolkan lokal konten sebagai dasar film animasinya .Oleh karena itubanyak elemen elemen yang menarik untuk di tinjau lebih dalam sehingga dapat menghasilkan base cerita yang lebih baik.

\section{Tinjauan Pustaka}

Sejarah Gang Kelinci

Sesak dan padat adalah gambaran yang cocok untuk menggambarkan salah satu pemukiman bersejarah yang dimiliki Kota Jakarta, yaitu Gang Kelinci. Tidak banyak orang yang mengetahui keberadaan dan sejarah Gang Kelinci itu sendiri, sekalipun warga asli Jakarta itu sendiri. Karena letaknya yang tidak jauh dengan salah satu tempat bersejarah juga di Jakarta yaitu Pasar Baru Jakarta. Sehingga membentuk pemikiran bahwa Gang Kelinci merupakan Pasar Baru. Tidak banyak artikel, jurnal hingga buku yang ditemukan yang terkait Gang Kelinci yang sebenarnya. Yang banyak dijumpai hanya artikel tentang kuliner Bakmi Gang Kelinci ( GK ), dan juga judul lagu Gang Kelinci.

\section{Teori Animasi}

Salah satu definisi yang menjelaskan animasi itu sendiri adalah sebuah sebuah film yang terbuat dari beberapa frame ilusi sebuah pergerakan atau ilusi yang bergerak. Norman McLaren mengatakan pendapatnya mengenai 
animasi yaitu “ Animasi bukanlah karya seni gambar yang bergerak namun sebuah karya seni gerakan yang digambar ". Animasi adalah gambar bergerak yang dibuat denga cara merekam gambar gambar diam, kemudian rekaman gambar gambar tersebut diputar berulang ulang dengan berurutan sehingga terlihat tidak lagi sebagai masing masing gambar yang terpisah, tetapi sebagai sebuah kesatuan yang menghasilkan ilusi pergerakan yang tidak terputus. Hingga menjadi salah satu cikal bakal animasi dua dimensi saat ini. Namun animasi sekarang telah berkembang terbagi menjadi dua yaitu animasi dua dimensi dan animasi tiga dimensi.

Animasi $3 D$ atau tiga dimensi merupkan sebuah animasi yang muncul dalam tiga dimensi yang memiliki ruang dan kedalaman, sehingga mereka terlihat seperti objek nyata yang memiliki perspektif.

Walaupun memiliki pengertian yang berbeda namun kedua jenis animasi tersebut memiliki prinsip yang sama. Yang membedakan hanyalah wujud bentuk penyampaiannya lah yang berbeda.

\section{Teori Mise-en-scène'}

mise-en-scène' merupakan salah satu dari beberapa element yang terdapat dalam sebuah film. mise-en-scène' digunakan dalam ilmu perfilman dalam mendeskripsikan tentang style visual. Kata tersebut berasal dari Bahasa Perancis meskipun telah digunakan dalam Bahasa Inggris sejak tahun 1833. Secara literal mise-en-scène' di artikan sebagai " to put on stage " atau untuk di tempatkan diatas panggung. Namun seiring berjalannya waktu terjadi pergeseran arti dan makna. Menjadi semua element yang muncul di dalam sebuah frame atau set, meliputi aktor, lighting, dekorasi, properti, kostum dan segala objek natural dan objek buatan yang mengkarateristikan sebuah film. Hal itu lah yang membuat gambaran visual yang berada dalam frame membentuk seuatu karakteristik visual dalam penyampaian setiap informasinya.

Mise-en-scène' pertama digunakan pada sebuah film di tahun 1950 oleh kritikus asal Perancis pada Cahiers $d u$ Cinéma atau (Notebooks on Cinema). Mereka meminjamnya dari sebuah teater di Perancis yang dimana memang di artikan kepada setiap hal yang muncul dalam stage, apapun yang terlihat didalam kamera mulai dari setting, lighting, aktor dan bagaimana mereka melakukan performance, hingga segala properti mulai dari kostum dan make up di setiap karatker yang muncul. Karena hal tersebut tidak lain untuk membangun emosi dan suasana untuk mendukung penyampaian setiap informasinya.

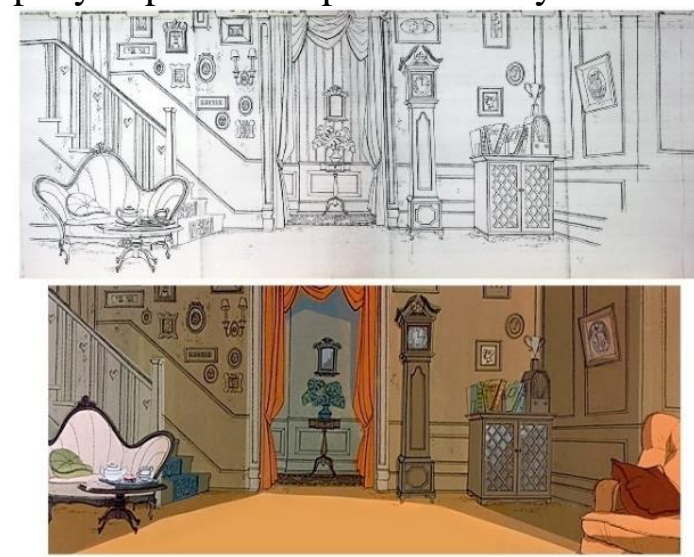

Gambar 2.1 Layout Dalam Animasi 2D

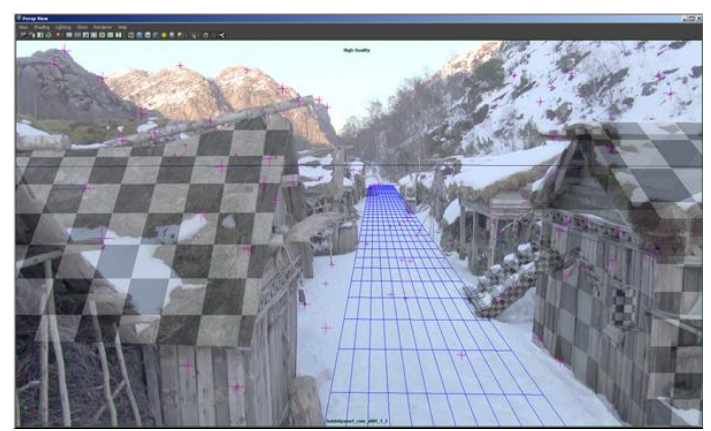

Gambar 2.2 Layout Dalam Animasi 3D

Dan hal tersebut berlaku juga terhadap film animasi, yang memang 
Mise-en-scène' masuk kedalam element sebuah film animasi yang dimana sebuah director memiliki peran dalam penempatan setiap gambar, garis, dan warna yang dibutuhkan dalam setiap scene nya. Sangat penting untuk diingat bahwa setiap asset yang terdapat dalam sebuah scene harus memiliki fungsi dan tujuan yang jelas, yang nantinya akan memberikan dampak besar terhadap informasi yang di sampaikan pada film tersebut. Dan juga memiliki memiliki beberapa area di setiap lapisannya, seperti foreground, ground, dan background yang akan membentuk sebuah dimensi di setiap setting.

Setting

Setiap setting dalam suatu perfilman dibuat untuk membentuk suasana dan sebuah rasa dari yang disampaikan yang juga mencerminkan sifat dari setiap karakter yang ada. Setiap setting yang digunakan pada umumnya yaitu setting buatan (di dalam sebuah ruangan atau studio) namun tidak semuanya buatan atau artificial seperti properti dan dekorasi buatannamun juga menggunakan real life shoot. Namun biasanya setting buatan biasanya sering digunakan karena sulinya mencari lokasi yang sesuai untuk digunakan namun akan memberikan dampak produksi ekstra dalam tahap postproduction.

Suasana malam di jakarta (lebih spesifik misalnya suasana malam di stasuin Jakarta) animasi

Studi set dalam Film dari general ke

1. Set asli

2. Set buatan

\section{METODE PENELITIAN DAN PERANCANGAN}

\section{Metode kualitatif}

Didefinisikan sebagai suatu pendekatan atau penelusuran untuk mengeksplorasi dan memahami suatu gejala sentral. Untuk mengerti gejala sentral tersebut peneliti mewawancarai peserta penelitian atau partisipan dengan mengajukan pertanyaan yang umum dan agak luas. Informasi tersebut biasanya berupa kata atau teks yang nantinya menjadi sebuah pengambaran atau deksprisi dll.

Dalam riset ini metode perancangan yang dilakukan yaitu dengan cara kualitatif, Seperti melakukan observasi ke tempat tempat yang berhubungan dengan riset ini. Dan juga pengumpulan data dari artikel artikel terkait dengan Gang Kelinci.

\section{Teknik Pengumpulan Data}

Teknik Dokumen

Penelitian yang dilakukan berupa pengumpulan data dari berbagai artikel terkait Gang Kelinci. Sehingga saya sebagai peneliti dapat memperoleh data awal mengenai sejarah Gang Kelinci dan infomasi lainnya yang nantinya akan dilanjutkan dengan melakukan Observasi lapangan.

\section{Teknik Observasi}

Penelitnan yang dilakukan berupa pengumpulan data dengan cara langsung ke lokasi Gang Kelinci. Sehingga peneliti dapat memperoleh data lebih detail dan lebih mendalam mengenai Gang Kelinci. Dan juga sebagai perbandingan dari data awal yang telah di dapatkan melalui artikel artikel. Dan yang paling penting ialah untuk merasakan suasana dari lokasi Gang Kelinci sehingga menghasilkan gambaran gambaran visual dari Lokasi Gang Kelinci yang nantinya digunakan sebagai dasar konsep tempat Short Animasi.

\section{Metode Perancangan}

Dalam sebuah perancangan, akan mengalami sesuatu yang dinamakan sebagai process design. "Design is process that turns a brief or requirement 
into a finished product or design solution". ( Gavin \& Paul, 2015 ). Process design itu sendiri memiliki beberapa pengertian dan penjelasan, namun pada umumnya menjelasakan sebuah proses yang berjalan dalam membuat suatu hal untuk menyelesaikan masalah yang ada. Process Design terdiri dari beberapa tahap yaitu, define, research, ideate, dan prototype.

Define

Yaitu merupakan sebuah tahap dalam mendifinisikan masalah yang ingin diangkat hingga tujuan apa yang akan didapatkan. Dan telah ditentukan permasalahan yang akan diangkat ialah sisi visual apa saja yang kuat dari daerah Gang Kelinci Pasar Baru Jakarta, yang dapat digunakan untuk membuat set dalam sebuah film animasi yang menekankan pendalaman kepada suatu suasana. Dan tujuannya ialah untuk mengetahui bagaimana suasana Daerah Gang Kelinci, dan visual dari tempat gang kelinci itu sendiri.

\section{Research}

Yaitu proses pencarian data, mulai dari pencarian melalui pustaka pustaka hingga yang saya lakukan adalah Observasi. Dimana sebagian besar akan melakukan kunjungan untuk pengambilan gambar - gambar atau video di Gang Kelinci Jakarta.

\section{Ideate}

Yaitu proses brainstorming terhadap data apa saja yang telah terkumpul. Sesuai dengan judul proposal yang diajukan, pada tahap ini saya akan melakukan eksplorasi terhadap data visual visual yang telah terkumpul, mulai dari penentuan point point ide, hingga menghasilkan sesuatu visual yang baru.

\section{Prototype}

Yaitu proses eksekusi dari sebuah ide menjadi wujud/bentuk visual yang dihasilkan mulai dari sketch hingga bentuk asset yang siap digunakan dalam proses Production dalam Animasi.

\section{HASIL DAN PEMBAHASAN}

\section{The Last Game}

Dari beberapa data riset yang telah diperoleh mengenai konten yang akan disampaikan, ada beberapa style art yang saya fikir cocok untuk diterapkan. Beberapa refrensi tersebut dipilih karena adanya beberapa kemiripan dalam environment yang ingin di perlihatkan.

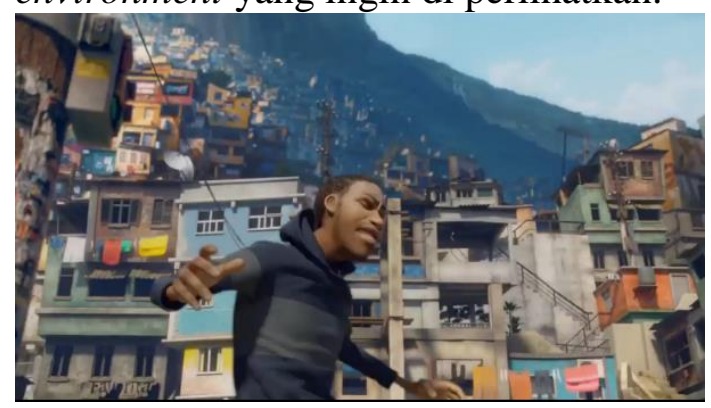

Gambar 2.3 Shot The Last Game

film tersebut merupakan film animasi pendek $3 D$ yang mengangkat tema tentang sepak bola dengan latar tempat salah satu pemukiman di Brazil yang terkenal akan kentalnya sepakbola disana.

Yang ingin dijadikan refrensi ialah bagaimana film tersebut mengolah dan membuat asset $3 D$ dari refrensi yang telah dilakukan.

Di antaranya ada beberapa cut dimana mengkombinasikan antara komposisi kamera horizontal yang memberikan kesan memiliki kekuatan dan komposisi kamera diagonal yang membangun rasa emotional dari film tersebut.

Warna yang diperlihatkan dari film tersebut beraneka ragam. Namun lebih terlihat lebih sedikit pudar dari warna dari refrensi aslinya. Yang terlihat lebih terang. Namun masih terlihat kesan bising dan ramainya aktifitas dari film tersebut. 
Terlihat dari angel kamera sedikit low angel melihat kearah karakter yang membuat karakter tersebut menjadi pusat focus dalam cut tersebut.

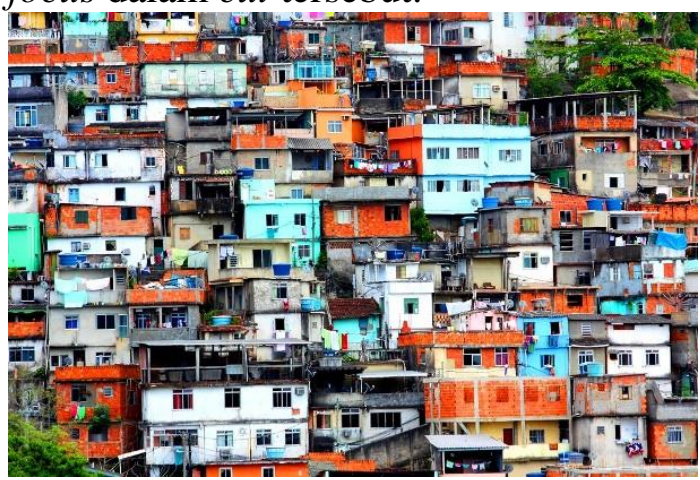

Gambar 2.4 Penampakan Bangunan Di Rio de Jeniro Brazil

Tidak begitu realistic namun sangat terlihat natural komposisi yang diberikan di latar setnya. Namun terlihat beberapa bangunan yang ter exaggerate yang memberikan kesan lebih natural, dari refrensi aslinya untuk menghindari terlihat seperti monoton.

Beberapa hal dalam Mise-en-scène yang diperhatikan dalam film tersebut ialah cinematography yang diterapkan, memberikan kesan surprise kepada penonton.

\section{Rubato}

film animasi pendek Rubato yang menceritakan tentang seorang kakek yang sedang bermain Double Bass, sejenis cello.Film tersebut dijadikan refrensi pada tone warna dan mood warna yang di perlihatkan. Terlihat warna yang digunakan tidak terlalu mencolok seperti biru, hijau tua, abu abu, coklat dan merah maroon. Memberikan kesan yang beragam, yaitu kesan damai dan juga sedikit kesan sedih dan putus asa. Dan di tengah tengah plotnya terjadi perpindahan mood warna yang disana ditandakan adanya masalah yang terjadi disana, sehingga menjadi warna kuning kecerahan.

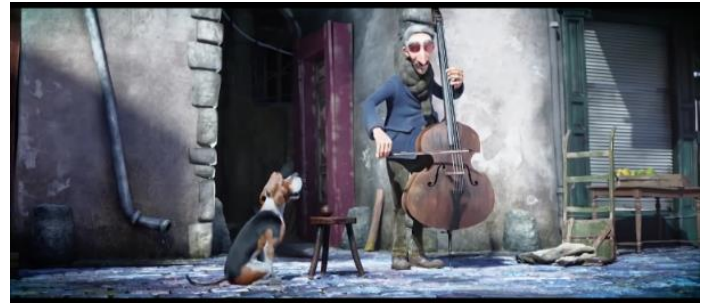

Gambar 2.5 Shot Rubato

Hal tersebut menandakan pentingnya permainan mood warna dalam sebuah film animasi, khususnya dalam membangun environment dan ambient feel kepada penonton.

\section{Rango}

Dengan mengangkat tema wild west, yang biasanya sedikit lebih geometris, namun dalam film tersebut terlihat sangat dynamis sehingga terlihat lebih natural dan indah tanpa menghilangkan kesan susah dan sengsara yang di berikan.

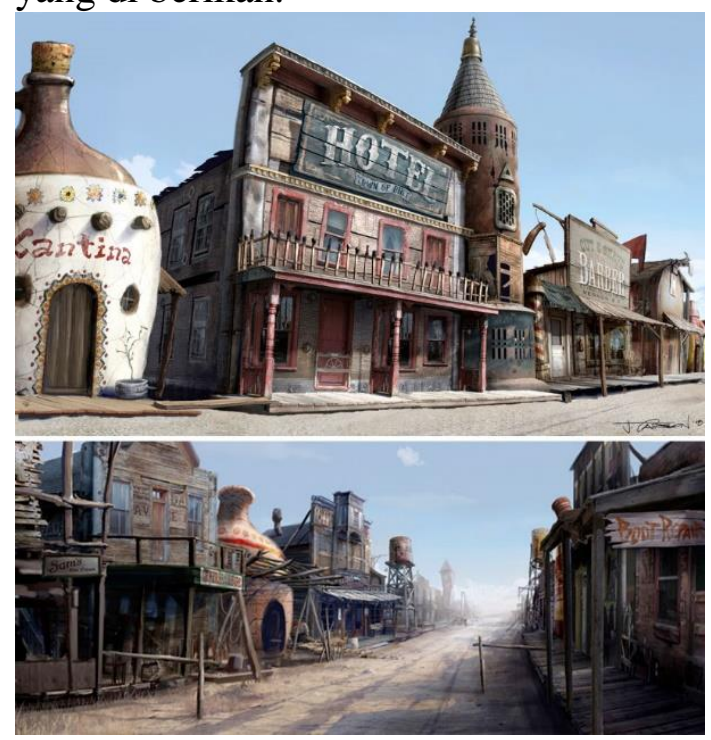

Gambar 2.6 Environment Film Animasi Rango

Dan juga beberapa refrensi bentuk visual dari concept yang ingin saya jadikan refrensi namun hanya sebagai konsep visual bentuk, bukan dijadikan sebagai konsep tema seperti wild west.

Dan beberapa ciri khas bangunan pada style wild west yang saya pikir sangat unik untuk saya coba kedalam konsep dasar saya. Bagaimana, terlihat 
bangunan tua yang kumuh dan rusak namun masih terlihat estetik dari bangunan tersebut.

\section{Team Fortress 2}

Beberapa refrensi style lainnya adalah salah satu game, Team Fortress 2. Yang memiliki kemiripan dalam style yang diangkat, yaitu wild west. Selain diguanak sebagai refrensi environment, game TeamFortres tersebut saya jadikan sebagai refrensi Render pada film yang ingin saya buat nanti. Karena saya anggap cocok terhadap mood warna yang ingin saya berikan nanti, dengan style visual yang ingin saya eksplorasi lebih dalam.

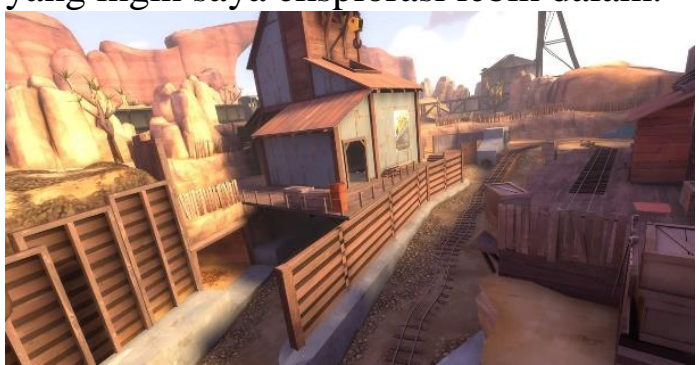

Gambar 2.7 Environment Map Dalam Game Team Fortress 2

\section{Gang Kelinci Jakarta}

Dari hasil observasi pertama Gang Kelinci Jakarta, merasakaan ambient suasana yang tidak jauh berbeda dari kunjungan saya sebelumya yang memang observasi kemari bukanlah kunjungan yang pertama kali untuk saya.

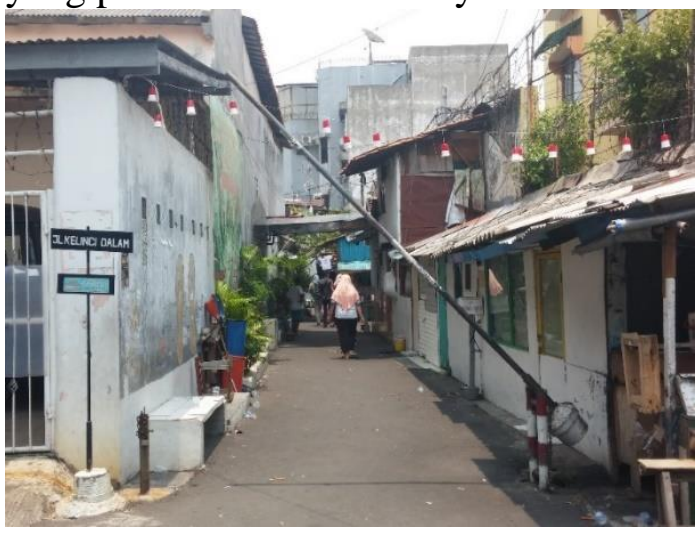

Gambar 2.8 Pintu Masuk Gang Kelinci Dalam

Penampakan pintu masuk Gang Kelinci Dalam Jakarta Pusat. Jika diambil dengan komposisi dan angel yang sesuai maka akan berpotensi menjadi salah satu cut pembuka awal di film animasi yang akan dibuat.

Terdapat sebuah portal di depan pintu masuk yang memiliki kesan pembuka atau introduction awal cerita terbuat atau cerita dimulai.

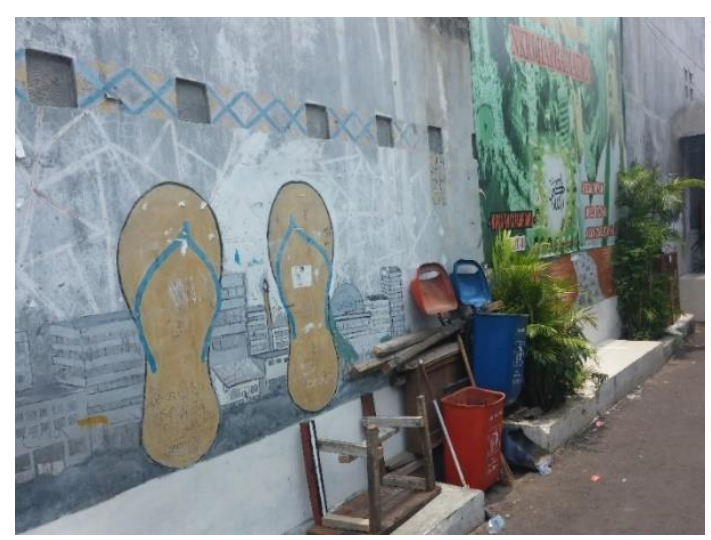

Gambar 2.9 Tembok di Salah Satu Gang Kelinci

Penampakan selanjutnya merupakan sebuah seni yang dibuat warga setempat, dalam rangka merayakan hari raya kemerdekaan beberapa tahun yang lalu.

Namun dari gambar pertama terlihat hiasan dari kemasan air minum tersebut merupakan hiasan kemerdekaan beberapa bulan lalu.

Sangat unik untuk dijadikan salah satu ide, dimana mereka yang tinggal disana ikut serta berpartisipasi dalam merayakan kemerdekaan bangsa. Menggambarkan mereka juga rakyat Indonesia, yang memiliki hak dan setara dengan masyarakat lain.

Masuk lebih dalam, terlihat betapa padatnya suasana di pemukiman tersebut. Terlihat banyaknya barang barang yang tipdak tertata, bukan berarti tanpa tujuan. Melainkan kurangnya tempat untuk menaruh barang tersebut di dalam rumah.

Dan juga terlihat betapa banyaknya pakaian yang sedar di jemur menandakan betapa banyaknya penghuni dari setiap rumah yang bias dibilang tidak terlalu lebar. Satu yang unik yaitu dimana meskipun terlihat kotor dan tidak tertata, 
namun dalam setiap kunjungan saya selalu mencium aroma sabun pencuci pakaian di setiap sudutnya.

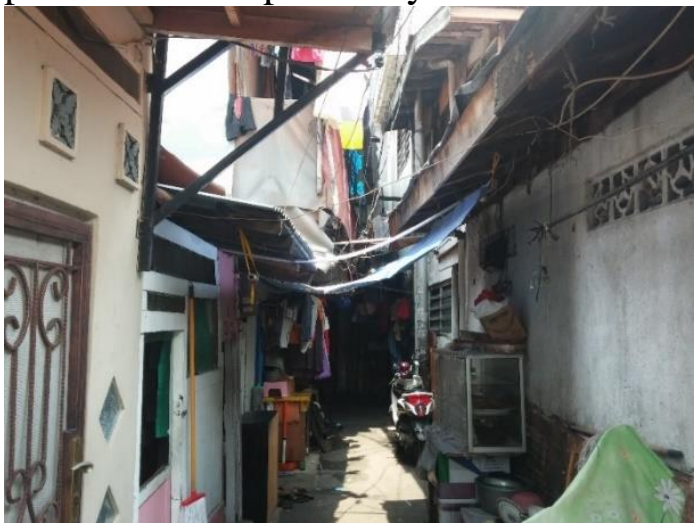

Gambar 2.10 Salah Satu Akses Jalan

Dan bisa diperhatikan karena padat dan rapatnya setiap pemukiman disana, bahkan sinar matahari pun sulit untuk masuk dan menyentuh tanah karena terhalang oleh atap dan sebagian pakaian.

Dari beberapa ulasan diatas terlihat beberapa plot atau ide yang bisa digunakan sebagai refrensi cerita dan penekanan visual terhadap ciri khas pemukiman tersebut.

Selanjutnya jika diperhatikan gambar sebelumnya ada suatu yang unik yaitu akses jalan yang mengarah kepada sebuah terowongan. Yang mengarah kepada pusat pemukiman disana. Yang dimana diatas terowongan tersebut terdapat rumah diatasnya.

Pada terowongan tersebut terlihat beberapa coretan coretan dari gambar yang kemungkinan dibuat oleh anak anak sekitar.

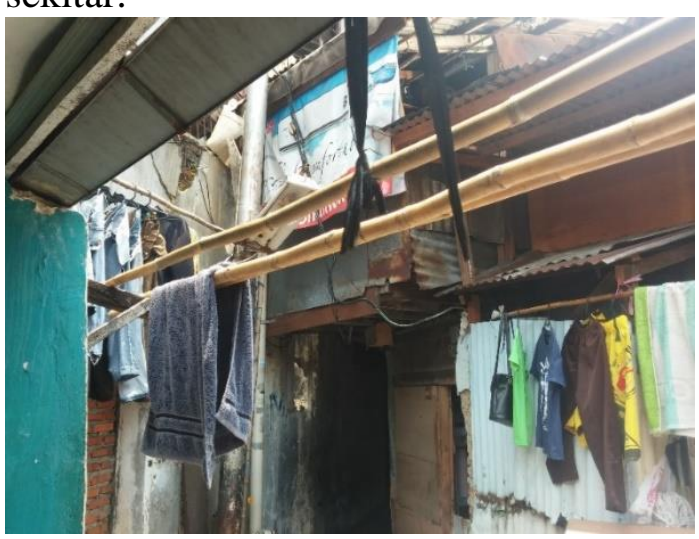

Gambar 2.11 Terowongan Akses Jalan
Hal tersebut merupakan gambaran yang sangat penting yang nantinya dijadikan sebuah film animasi pendek. Yang dimana terowongan tersebut seperti lorong yang menuju ketempat pusat pemukiman. Dimana banyaknya rumah rumah warga yang sama sekali tidak terlihat dari luar.

Gambar selanjutnya merupakan sebuah pompa air yang dahulunya masih dapat berkerja. Satu dari beberapa pompa air yang sudah jarang sekali ditemui di beberapa pemukiman di Jakarta.

Pompa tersebut dahulunya prasarana umum yang digunakan setiap paginya bersama sama oleh penduduk setempat untuk mencuci pakaian hingga mandi.

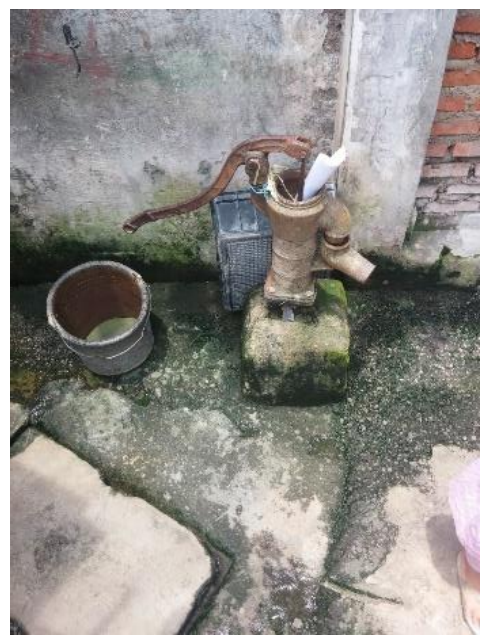

Gambar 2.12 Pompa Air Tua

Yang nantinya akan digunakan menjadi salah satu asset dalam membangun suasana traditional yang sudah jarang sekali ditemu disana.

Sebagian bangunan disana adalah bangunan semi permanen dengan campuran semen dan teriplek dan beratapkan seng besi. Yang dimana susunan setiap bangunannya tidak memiliki model, bertumpuk hanya untuk tidak terlihat dari luar ke dalam rumah.

Dan juga terlihat dari pemukiman setempat, dari kejauhan nampak banyak apartement dan gedung perkantoran yang menjulang, disekitar Gang Kelinci. 


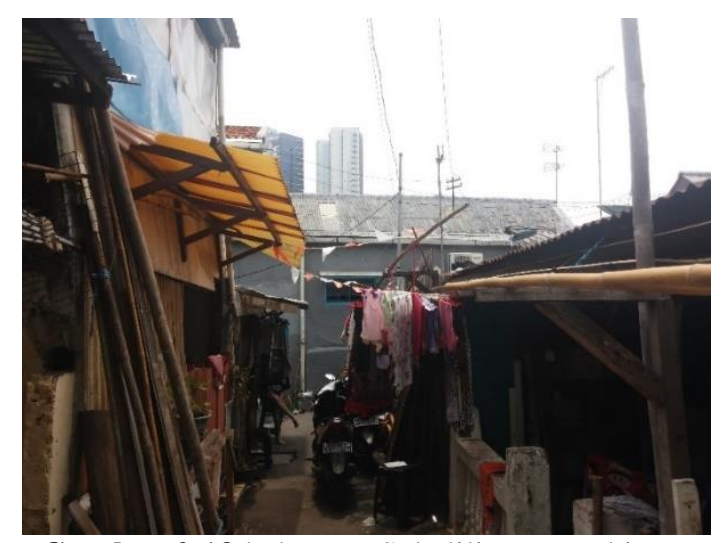

Gambar 2.13 beberapa Sekeliling Pemukiman

Seolah pemukiman tersebut terlihat dikelilingi oleh gedung gedung bertingkat. Seakan menjadi pagar yang mengurung sebuah tempat kecil.

Dari dua gambar terakhir terlihat betapa perbedaan yang luar biasa dari sudut visual. Yaitu bangunan permanen yang cenderung lebih semi modern, dengan banunan yang semi permanen tradisional yang tidak terlalu tertata.

Hal tersebut lah yang selain akan digunakan sebagai ide dalam perancangan set sebuah film animasi, juga nantinya akan menjadi refrensi cerita dari film animasi tersebut.

\section{Penulisan Judul}

Untuk design judul, penulis menggunakan font Brainfish Rush terlihat memiliki stroke dan shadow pada fontnya yang memberikan kesan fun didalamnya. Tulisan Home sebagai gambaran kehidupan dan tempat dimana sebuah pemukiman hidup dan berkembang disana. Bagaimana terlihat di sekitar font tersebut terdapat background seperti banngunan atau gedung gedung bertingkat yang melambangkan tempat asli gang kelinci itu yang di kelilingi oleh gedung gedung perkantoran. Dan juga terlihat ada sedikit bentuk seperti rumah yang menempel di huruf $\mathrm{H}$ yang melambangkan tempat tinggal dari pemukiman gang kelinci yang sebagian besar sangat sempit dan menempel satu dengan yang lainnya.

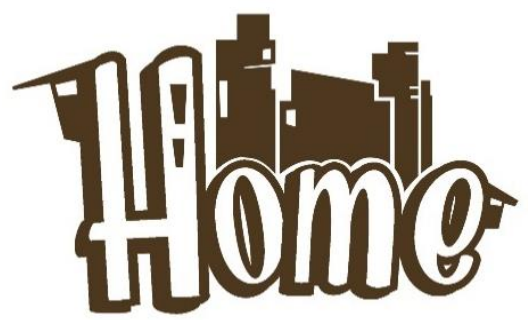

Gambar 2.14 Judul "Home"

Boy

Merupakan seorang anak dari sebuah perkampungan yang berumur 19 tahunan yang hendak mencari tempat tinggal di daerah Jakarta sebagai tempat sementara selagi ia menjalani perkuliahannya di salah satu universitas di Jakarta. Anak muda tersebut tidak memiliki ke unikan tertentu dalam hal sikap maupun prilaku, yang terlihat seperti anak muda pada umumnya yang kenal dengan teknologi pada eranya. Dengan tidak memeliki keunikan inilah semoga dapat membangun relasi dengan cepat kepada penonton sehingga mencerminkan masing masing dari sifat mereka pada umumnya. Namun pada sedikit sifat yang lebih menonjol pada anak muda ini adalah sifat takutnya ia terhadap lingkungan yang baru ia kunjungi nanti. Seperti anak muda pada umumnya yang tidak jauh dari gadget smartphone nya dan juga beberapa teknologi seperti laptop dan lainnya. Dan juga di lengkapi dengan atribute sebagai pembangun identitas nya sebagai anak Rantauan yaitu tas ransel besar beserta Koper yang berisi baju baju.

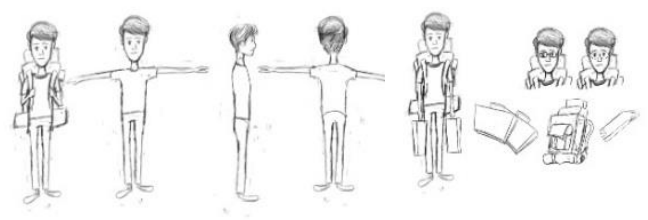

Gambar 2.15 Karakter Anak Muda dan Atribute 


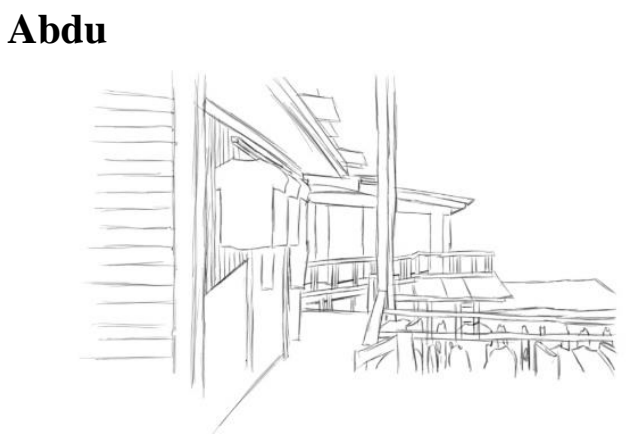

Merupakan seorang bocah kecil yang berumur sekitar 7 tahunan yang memiliki sifat jahil dan sering melakukan kegaduhan di pemukiman tersebut. Bocah itu tinggal sendiri dalam pemukiman tersebut yang membuat karakter dan sifatnya terbentuk sedemikian rupa. Anak itu memiliki bentuk yang cukup unik, yaitu ia tidak bisa lepas dari sebuah bak mandi kecil yang terbuat dari plastik yang digunakannya sebagai penutup di kepala seperti topi. Dengan latar belakang anak yang hidup sendiri, namun bocah tersebut jarang memperlihatkan sifat sedih dan kesepian karena rasa itu seolah hilang dari kesibukannya yang hanya bermain dan membuat onar di pemukiman itu.
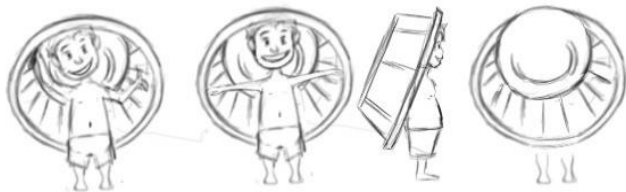

Gambar 2.16 Karakter Anak Bocah

\section{Pemukiman Gang Kelinci}

Pemukiman yang dibentuk kali ini berbeda dari pemukiman pada aslinya yaitu berubah status menjadi tempat kost atau rumah susun. Meskipun begitu, penulis tidak akan menghilangkan kesan atau identitas lama yang berciri khas dari gang kelinci yang asli. Seperti kesan padat dan berantakan yang menjadi identitas dari pemukimannya. Yang dipenuhi beberapa baju baju pakaian yang bergantung di jemuran.
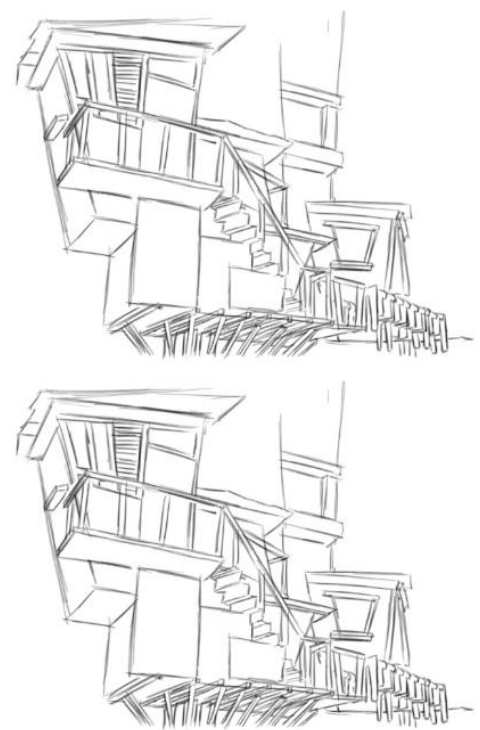

Gambar 2.17 pemukiman Gang Kelinci

Dan juga banyak orang dari berbagai sifat yang hidup didalamnya. Dan untuk pendekatan style yang dipilih cenderung lebih realist dengan warna flat tanpa tekstur, yang penulis anggap sesuai untuk digunakan nanti.

Dan juga beberapa element element yang penulis ambil dari pemukiman gang kelinci yang asli yaitu pompa air yang masih tradisional dan juga adanya terowongan yang menuju kearah pusat pemukiman dari gang kelinci itu sendiri
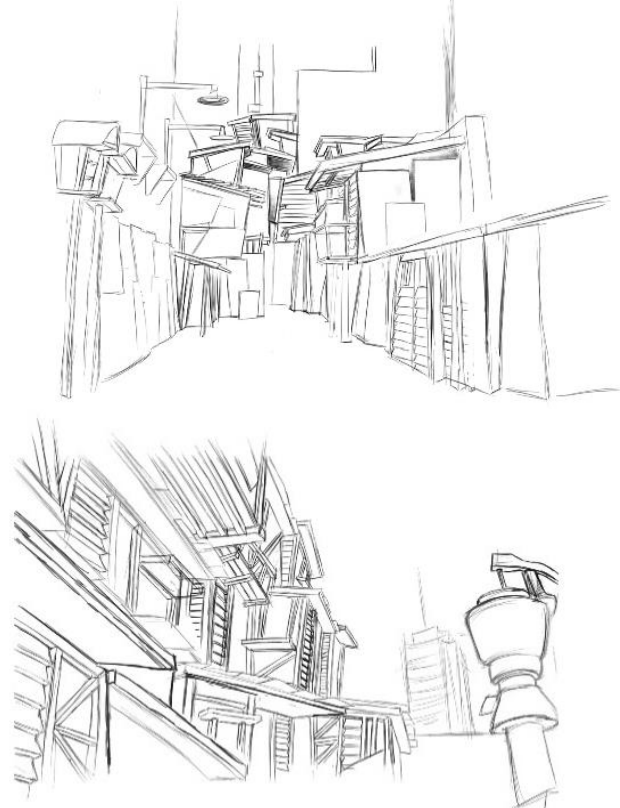

Gambar 2.18 pemukiman Gang Kelinci 


\section{Story Style}

Cerita pada animasi ini dibuat akan lebih menonjolkan pada sisi environmentnya yang nantinya dari sudut pandang karakter utama lah yang bercerita bagaimana suasana dari pemukiman di gang kelinci itu sendiri. Banyak plot plot yang di tunjukan guna untuk membangun suasana dari tempat gang kelinci. Untuk cerita itu sendiri cenderung lebih kearah komedi dengan plot plot yang dibuat sedemikian rupa untuk menggiring kepada masalah awal yang akan muncul.

\section{Visual Style}

Untuk visual style banyak penekanan exaggerate pada sisi environment bangunan untuk meninmbulkan kesan aneh dan asing dari setting yang akan dijumpai karakter utama nanti. Banyak element dan warna coklat yang dianggap lebih menampilkan sisi kehidupan yang dianggap cocok pada cerita yang diangkat. Beberapa bangunan sebagian besar terbuat dari kayu yang beratapkan seng besi. Tekstur yang digunakan nantinya adalah flat color tanpa tekstur dari setiap objek nya. Meskipun flat nantinya akan menonjoklan depth of field dari setiap cinematography sehingga memberikan kesan adanya volume dari setiap objeknya.

\section{SIMPULAN}

Dalam pembuatan short animasi pada umumnya banyak aspek yang harus diperhatikan mulai dari segi cerita, karakter, hingga environment yang nantinya akan membentuk suatu susunan yang saling melengkapi. Karena dalam membuat animasi kita harus memiliki sebuah materi dasar dan konsep yang matang dan juga eksekusi yang baik juga menjadi salah satu dari beberapa faktor dalam pembuatan film animasi. Dengan begitu dibutuhkannya lah riset mengenai dasar dan konsep dari setiap animasi yang diangkat. Seperti animasi ini yang penulis buat dalam menunjukan dan bercerita yang menonjolkan segi environment nya. Akan sangat sulit jika tidak memiliki data yang kuat dalam pembuatan short animasinya nanti. Sehingga banyak menggunakan plot kejadian kejadian dalam membangun cerita dari sebuah kehidupan yang terjadi di Gang Kelinci.

\section{DAFTAR PUSTAKA}

Nelmes, J. (2003). Animation : Forms and Meanings. In J. Nelmes, An Introduction to FILM STUDIES Third Edition (p. 214). London: Routledge.

Gavin Ambrose, P. H. (2015). Stages of thinking. In P. H. Gavin Ambrose, DESIGN THINKING FOR VISUAL COMMUNICATION (p. 9). London, New york: Bloomsbury Publishing.

Gibbs, J. (1893). THE ELEMENT OF MISE-EN-SCÈNE'. In J. Gibbs, MISE-EN-SCÈNE' Film Style and Interpretation (p. 5). New York: Columbia University Press.

(n.d.). $\quad$ Retrieved from http://www.academia.edu/97177 76/Developments_in_Film_Theo ry_Arguments_Through_Mise_e n_sc\%C3\%A8ne

Ambrose, Gavin; Harris, Paul. (2006). The Fundamentals of Typography. Lausanne, Switzerland: AVA Publishing SA.

Ambrose, Gavin; Harris, Paul. (2009). The Fundamentals of Graphic Design. Lausanne, Switzerland: AVA Publishing SA. 
College Film and Media Studies ( A Reference Guide ). (2017, September 15). Retrieved from College Film and Media Studies: https://collegefilmandmediastudi es.com/mise-en-scene-2/

Creativity, Java. (2014). Panduan Cerdas Membangun Website Super Keren. Jakarta: PT. Elex Media Komputindo.

Developments in Film Theory: Arguments Through Mise en scène. (2017, september 16). Retrieved from Academia: http://www.academia.edu/97177 76/Developments_in_Film_Theo ry_Arguments_Through_Mise_e n_sc\%C3\%A8ne

Garrett, Jesse James. (2011). The Elements of User Experience, User-Centered Designs For The Web And Beyond Second Edition. Berkeley: New Riders.

Gavin Ambrose, P. H. (2015). Stages of thinking. In P. H. Gavin Ambrose, DESIGN THINKING FOR VISUAL COMMUNICATION (p. 9). London, New york: Bloomsbury Publishing.

Gibbs, J. (1893). THE ELEMENT OF MISE-EN-SCÈNE'. In J. Gibbs, MISE-EN-SCÈNE' Film Style and Interpretation (p. 5). New York: Columbia University Press.

Holzschlag, Molly E. (2004). 250 HTML and Web Design Secrets. Indianapolis: Wiley Publishing, Inc.

Johnson, Steve. (2012). Adobe $\AA$ Dreamweaver ${ }^{\circledR}$ CS6 on Demand. Indiana Polis: QUE Publishing.
Kampung Venus: Labirin Gang Kelinci Ibukota, Matahari pun Sulit Tembus. (2017, October 5). Retrieved from detiknews: https://news.detik.com/berita/229 6560/kampung-venus-labiringang-kelinci-ibukota-mataharipun-sulit-tembus

Martin, M. (2011). Typographic Design Patterns and Best Practices. In S. Magazine, Typography: Getting the Hang of Web Typography (p. 87). Freiburg: Smashing Media $\mathrm{GmbH}$.

Mise-en-scène. (2017, September 15). Retrieved from the ELEMENTS OF CINEMA BLOG \& PODCAST:

http://www.elementsofcinema.co $\mathrm{m} /$ directing/mise-en-scene-infilms/

Nelmes, J. (2003). Animation : Forms and Meanings. In J. Nelmes, $A n$ Introduction to FILM STUDIES Third Edition (p. 214). London: Routledge. Retrieved from https://books.google.co.id/books? $\mathrm{id}=\mathrm{jcC}$ ADouuE_UC\&pg=PA214 $\& \mathrm{dq}=$ short+animation+definition $\&$ hl $=\mathrm{id} \& \mathrm{sa}=\mathrm{X} \& \mathrm{ved}=0 \mathrm{ahUKEwiz}$ 6bbPl_XWAhXEopQKHXRCAe AQ6AEIJjAA\#v=onepage $\& \mathrm{q}=\mathrm{sh}$ ort\%20animation\%20definition\& $\mathrm{f}=$ false

Nelmes, J. (2003). Animation : Forms and Meanings. In J. Nelmes, $A n$ Introduction to FILM STUDIES Third Edition (p. 214). London: Routledge.

PASSION ANIMATION STUDIOS. (2017, 11 6). Retrieved from PASSION ANIMATION STUDIOS:

http://theinspirationroom.com/dai 
ly/commercials/2014/6/nike_foot ball_team_rio.jpg

Sihombing, Danton. (2015). Tipografi Dalam Desain Grafis. Jakarta: PT. Gramedia Pustaka Utama.

Sulianta, Feri. (2010). IT Ergonomics. Jakarta: PT. Elex Media Komputindo.
What Mise-en-scène Is and Why It Matters. (2017, september 16). Retrieved from IndieWire: http://www.indiewire.com/2014/ 06/what-mise-en-scene-is-andwhy-it-matters-133415/ 